\title{
Effects of nitrogen application on corn yield after harvesting the apical ear as baby corn
}

\author{
Paulo Sérgio L Silva; Bernardo B Araújo Júnior; Vianney R Oliveira; Frederico ST Pontes; Odaci F \\ Oliveira \\ UFERSA, C. Postal 137, 59625-900 Mossoró-RN; paulosergio@ufersa.edu.br
}

\begin{abstract}
Removal of the first female inflorescence in corn induces the plant to produce new inflorescences, which allows the first ear to be harvested as baby corn and the second to be harvested as green or mature ear (dry corn). The objective of this study was to compare the following production systems fertilized with nitrogen levels $(0$, 80 , and $\left.160 \mathrm{~kg} \mathrm{ha}^{-1}\right)$, applied to corn hybrid AG 1051: baby corn harvesting $(\mathrm{BC})$; green ear harvesting (GC); mature ear harvesting (DC); and harvesting of the first female inflorescence as baby corn + harvesting the other ears as green corn $(\mathrm{BC}+\mathrm{GC})$ or as dry corn $(\mathrm{BC}+\mathrm{DC})$. A randomized complete block design with split-plots (nitrogen in plots) and nine replicates was used. The BC system provided higher baby corn yields than the $\mathrm{BC}+\mathrm{GC}$ or the $\mathrm{BC}+\mathrm{DC}$ systems. For all traits employed to evaluate green corn yield, the $\mathrm{GC}$ system provided higher yields than the $\mathrm{BC}+\mathrm{GC}$ system. The $\mathrm{BC}+\mathrm{DC}$ system provided lower grain yield than the DC system. The application of nitrogen provided increases in all traits evaluated, except for number of kernels ear ${ }^{-1}$ and 100-kernel weight. The revenue (total and additional total) and additional profit values, in descending order, were obtained with the $\mathrm{BC}, \mathrm{BC}+\mathrm{GC}, \mathrm{BC}+\mathrm{DC}, \mathrm{GC}$, and DC systems, for all nitrogen levels. The values for those measurements increased as nitrogen dose increased. At the dose of $80 \mathrm{~kg} \mathrm{~N} \mathrm{ha}^{-1}$, the highest profitability index (percentage of additional revenue that is converted into additional profit) was obtained from DC sales. However, with the application of the highest nitrogen rate, the highest profitability was obtained from BC sales.
\end{abstract}

Keywords: Zea mays, green corn, grain yield, prolificacy.

\section{RESUMO}

Efeitos da aplicação de nitrogênio sobre o rendimento do milho após a colheita da espiga apical como minimilho

A remoção da primeira inflorescência feminina do milho induz a planta a produzir novas inflorescências, o que possibilita a colheita da primeira espiga como minimilho e a segunda, como espiga verde ou madura (milho seco). O objetivo do trabalho foi comparar, em doses de nitrogênio $\left(0,80\right.$ e $\left.160 \mathrm{~kg} \mathrm{ha}^{-1}\right)$, os seguintes sistemas de produção, aplicados ao híbrido AG 1051: colheita de minimilho (BC); colheita de espigas verdes (GC); colheita de espigas maduras (DC); e colheita da primeira inflorescência feminina como minimilho e colheita das outras espigas como milho verde $(\mathrm{BC}+\mathrm{GC})$ ou como milho seco (BC + DC). Utilizou-se o delineamento de blocos completos casualizados com parcelas subdivididas (nitrogênio nas parcelas) e nove repetições. $\mathrm{O}$ sistema $\mathrm{BC}$ propiciou maiores rendimentos de minimilho que os sistemas $\mathrm{BC}+\mathrm{GC}$ ou $\mathrm{BC}+\mathrm{DC}$. Em todas as características utilizadas na avaliação do rendimento de milho verde, o sistema GC propiciou maiores rendimentos que o sistema $\mathrm{BC}+$ GC. O sistema BC + DC proporcionou menor rendimento de grãos do que o sistema DC. A aplicação de nitrogênio propiciou aumentos em todas as características avaliadas, exceto no número de grãos espiga $^{-1}$ e massa de 100 grãos. Os valores das receitas (total e total adicional) e do lucro adicional, em ordem decrescente, foram obtidos com os sistemas $\mathrm{BC}, \mathrm{BC}+\mathrm{GC}, \mathrm{BC}+\mathrm{DC}, \mathrm{GC}$ e $\mathrm{DC}$, em todas as doses de nitrogênio. Os valores dessas medidas aumentaram com o aumento da dose de nitrogênio. Com a aplicação de $80 \mathrm{~kg}$ de $\mathrm{N} \mathrm{ha}^{-1}$, o maior índice de lucratividade (percentagem da receita adicional que é convertida em lucro adicional) foi obtido com a comercialização do DC. Mas com a aplicação da dose máxima de nitrogênio, obteve-se maior lucratividade com a comercialização de BC.

Palavras-chave: Zea mays, milho verde, rendimento de grãos, prolificidade.

(Recebido para publicação em 6 de março de 2012; aceito em 25 de julho de 2013)

(Received on March 6, 2012; accepted on July 25, 2013)

$\mathrm{B}$ aby corn consists of corn ears harvested two to three days after silk emergence. It is used as human food, either fresh or canned. Green ears are immature corn ears whose kernels have a moisture content from 70 to $80 \%$; they are used as human food in a variety of forms. Dry grains are mature grains used as human and animal food as well as for industrial use.

Some corn cultivars are prolific, that is, they have the capacity to produce more than one ear per plant, although only one or two will reach maturity. Prolificacy manifestation, which is dependent upon genotypic and environmental factors (Motto \& Moll, 1983), requires a threshold to be achieved in order for a second ear to develop. Certain environmental conditions may not be sufficient for the plant to attain such threshold and thus become prolific. Under these conditions, all available metabolic energy is used towards apical growth (first ear). However, when the available environmental resources are sufficient to secure prolificacy, part of 
the metabolic energy is used for the production of a second or subapical ear (Hallauer, 1974).

No matter if a corn cultivar is prolific or not, removal of the first ear normally induces the plant to produce new female inflorescences (Silva, 2001), which may give rise to other ears. This allows the first ear to be harvested as baby corn and the second to be harvested as green or mature ear, ensuing flexibility during crop exploitation. The productive potential of the first ear is lower than the second ear (Svečnjak et al., 2006); the hypothesis of our study, however, is that the combined yield of both products can be more advantageous than the yield of each product individually. A study on harvesting baby corn + green corn or baby corn + grain (Silva et al., 2006) showed that the best net incomes from an economic point of view would be obtained by exploiting the crop for the production of green ears, green ears + baby corn, baby corn, baby corn + grain, and grain, in this order (Silva et al., 2006). Another study about the theme was conducted by Wang et al. (2010) who compared the following treatments: 1) no baby corn (BC) harvest, only grain maize (GM) harvest; 2) first harvest as $\mathrm{BC}$, final harvest as GM; 3) first and second harvests as $\mathrm{BC}$, final harvest as GM; and 4) first, second, and third harvests as BC, final harvest as GM. Results indicated that the descending sequence of treatments for economic returns were treatments $4,3,2$, and 1 .

The flexibility provided by harvesting several products from the same crop allows the grower to compete with better conditions in the markets, by offering a wider range of products. Nevertheless, several issues must be addressed relative to cultivars and cultural practices so that the grower can exploit the possibility of producing baby corn and green ears or grain simultaneously. In this respect, nitrogen rate evaluation should be highlighted, since nitrogen is one of the most important fertilizers in corn crops.

Many studies have demonstrated the beneficial influence of nitrogen doses on corn dry grain yield (Blumenthal et al., 2003; Amaral Filho et al., 2005; Kamara et al., 2005), green ear yield (Silva et al., 2003), and baby corn yield (Thakur et al., 1998). Studies on nitrogen doses have still been interesting for researchers since the response provided by nitrogen on corn yield depends on both genotypic (Kamara et al., 2005; Cancellier et al., 2011) and environmental influences (Vetsch \& Randall, 2004). In addition, nitrogen levels may influence differently the growth of apical and subapical ears (Durieux et al., 1994).

The objective of this study was to compare the following production systems, applied to the cultivar AG 1051, under different nitrogen levels: harvesting all ears as baby corn, green ears, or mature ears; and harvesting the first female inflorescence as baby corn and the subapical ears as green corn or as mature corn.

\section{MATERIAL AND METHODS}

The experiment was conducted in field at Universidade Federal Rural do Semi-Árido, located in the district of Alagoinha, $20 \mathrm{~km}$ away from the municipal seat of Mossoró, Rio Grande do Norte state, Brazil (5¹1'S, 37²0’W, $18 \mathrm{~m}$ elevation), from August to December, 2009. According to Köppen (1948), the climate in the region is semiarid, classified as BSwh and has two climatic seasons: a dry season generally extending from June to January, and a rainy season from February to May. The mean maximum temperature in the region is between 32.1 and $34.5^{\circ} \mathrm{C}$ and the mean minimum is between 21.3 and $23.7^{\circ} \mathrm{C}$, with June and July as the coolest months, while the mean annual precipitation is around $825 \mathrm{~mm}$ (Carmo Filho \& Oliveira, 1989). Insolation increases from March to October, with a mean of $241.7 \mathrm{~h}$; the maximum relative humidity reaches $78 \%$ in April while the minimum is $60 \%$ in September (Carmo Filho \& Oliveira, 1989).

According to the Brazilian Soil Classification System, the soil in the experiment area is a Eutrophic RedYellow Argisol (Embrapa, 2006), and is classified as a Ferric Lixisol according to the Soil Map of the World (FAO, 1988). The analysis of a soil sample, collected at a 0-20 cm depth, showed the following results: $\mathrm{pH}\left(\mathrm{H}_{2} \mathrm{O}\right)=5.5$; organic matter $=25 \mathrm{~g} \mathrm{dm}^{-3}$; $\mathrm{P}($ Mehlich $)=$
$9 \mathrm{mg} \mathrm{dm}^{-3} ; \mathrm{K}^{+}=1.8 \mathrm{mmol}_{\mathrm{c}} \mathrm{dm}^{-3} ; \mathrm{Ca}^{2+}=$ $23 \mathrm{mmol}_{\mathrm{c}} \mathrm{dm}^{-3} ; \mathrm{Mg}^{2+}=7 \mathrm{mmol}_{\mathrm{c}} \mathrm{dm}^{-3} ; \mathrm{H}^{+}$ $+\mathrm{Al}^{3+}=18 \mathrm{mmol}_{\mathrm{c}} \mathrm{dm}^{-3} ; \mathrm{SB}=32 \mathrm{mmol}_{\mathrm{c}}$ $\mathrm{dm}^{-3} ; \mathrm{CEC}=49 \mathrm{mmol}_{\mathrm{c}} \mathrm{dm}^{-3} ; \mathrm{B}=0.34 \mathrm{mg}$ $\mathrm{dm}^{-3} ; \mathrm{Cu}($ Mehlich $)=0.5 \mathrm{mg} \mathrm{dm}^{-3} ; \mathrm{Fe}$ $($ Mehlich $)=33 \mathrm{mg} \mathrm{dm}^{-3} ;$ Mn $($ Mehlich $)=$ $16.9 \mathrm{mg} \mathrm{dm}^{-3} ; \mathrm{Zn}($ Mehlich$)=1.1 \mathrm{mg}$ $\mathrm{dm}^{-3}$.

The hybrid AG 1051 was submitted to different nitrogen levels $(0 ; 80$; and $160 \mathrm{~kg} \mathrm{ha}^{-1} \mathrm{~N}$ applied as ammonium sulfate) and to the following production systems: baby corn harvesting; green ear harvesting; mature ear harvesting; harvesting the first female inflorescence as baby corn and harvesting the subapical ears as green corn or mature (dry) corn. The adoption of only three nitrogen levels is not interesting to fit regression equations. However, in this investigation our goal was not to identify the ideal nitrogen rate for each production system mentioned above, but to evaluate the effects of nitrogen on the various production systems. In addition, the adoption of additional nitrogen levels would increase the number of treatments excessively, which could jeopardize local control. A randomized complete block design with split-plots was adopted (nitrogen levels applied in plots and production systems in subplots), with nine replicates. Each subplot consisted of three $6.0 \mathrm{~m}$-long rows spaced $1.0 \mathrm{~m}$ apart with pits spaced $0.4 \mathrm{~m}$ apart. In each subplot the area employed to evaluate corn traits (usable area) was the area occupied by the central row, with the elimination of plants in the last pit at both ends of each row.

The soil was tilled by means of two harrowings and planting fertilization consisted of one third of the $\mathrm{N}$ dose, $60 \mathrm{~kg} \mathrm{P}_{2} \mathrm{O}_{5}$, and $30 \mathrm{~kg} \mathrm{~K}_{2} \mathrm{O}$ per ha, using ammonium sulfate, single superphosphate, and potassium chloride, respectively. Seeding was performed by hand on August 27, 2009 using four seeds per pit. A thinning operation was performed 23 days after sowing, leaving the two more vigorous plants in each pit. Therefore, after thinning the programmed sowing stand in the experiment was 50 thousand plants ha-1.

The experiment was sprinklerirrigated, with experimental plots 
arranged in a parallel fashion with respect to the row of sprinklers. The water depth required for corn $(5.6 \mathrm{~mm})$ was calculated considering a root system operating depth of $0.40 \mathrm{~m}$. Irrigation time was based on the water retained in the soil at a tension of $0.04 \mathrm{MPa}$. A twoday watering schedule was adopted, with three weekly applications. Irrigation was initiated after planting and suspended 14 days before harvesting the dry corn.

The fall armyworm (Spodoptera frugiperda) was controlled with two Deltamethrin sprays ( 5 g a.i. ha-1) made 16 and 30 days after sowing. Weed control was performed by means of two manual hoeings conducted at 23 and 40 days after sowing, respectively. After each hoeing, a sidedressing fertilization was made with one third of the total $\mathrm{N}$ dose programmed, using ammonium sulfate.

The baby corn was harvested two to three days after silk emergence. The total number and weight of ears and the number and weight of marketable husked ears were evaluated. We considered marketable husked ears as those with good health showing a color varying from pearly white to light yellow, cylindrical in shape, with a diameter ranging from 0.8 to $1.8 \mathrm{~cm}$ and length ranging from 4 to $12 \mathrm{~cm}$ (Carvalho et al., 2003).

The green corn was harvested when the grain showed moisture contents between 70 and $80 \%$. The total number and weight of ears and the number and weight of marketable ears, either unhusked or husked were evaluated. Marketable unhusked ears were considered those free from damage caused by pests or diseases and with a length of $22 \mathrm{~cm}$ or longer, and marketable husked ears were those with health and grain set suitable for the market, presenting a length of $17 \mathrm{~cm}$ or longer (Silva et al., 2006).

The dry corn was harvested when the kernels showed a moisture content around 20\%. Evaluations were made for number of ears ha-1 (based on ears harvested from the usable area), number of kernels per ear (in 15 ears taken at random), 100-kernel weight (estimated based on 5 samples), and grain yield, corrected to a moisture content of
$15.5 \%$.

The data were submitted to analysis of variance using SAEG-software developed by Universidade Federal de Viçosa (Ribeiro Júnior, 2001).

An economic analysis was also carried out. In that analysis, it was considered that the total costs do not differ in each of the various production systems when the same nitrogen rate is applied. There are differences between

production system groups only when they are submitted to different nitrogen doses, since systems that receive fertilization require investment in nitrogen and in the application of this fertilizer. Therefore, we chose to use the concept of total additional cost, i.e., the total cost value that exceeds the total cost in production systems that did not receive nitrogen. A similar analysis has been utilized by other authors (Lima et

Table 1. Baby corn ear yield means in corn cultivar AG 1051 depending on production systems and the application of different nitrogen levels (médias do rendimento de espigas de minimilho da cultivar de milho AG 1051, em função de sistemas de produção e da aplicação de doses de nitrogênio). Mossoró, UFERSA, 2009.

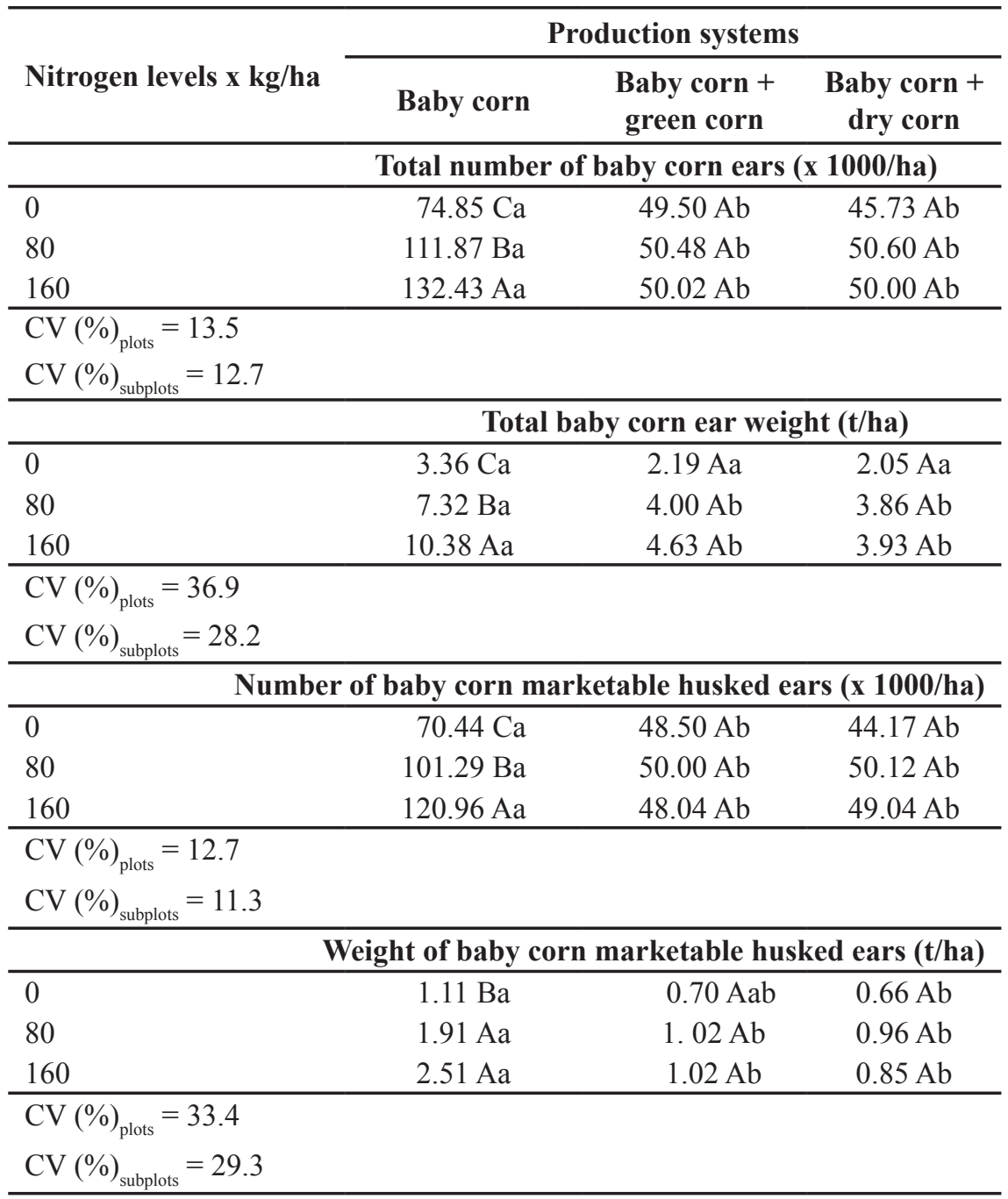

In each trait, means followed by the same uppercase letter in the column, and by the same lowercase letter in the row do not differ from one another, Tukey 5\%; Baby corn $=$ all ears produced were harvested as baby corn; baby corn + green corn and baby corn + dry corn $=$ the first ear was harvested as baby corn and the others were harvested as green corn or mature corn, respectively (em cada característica, médias seguidas pela mesma letra maiúscula, na coluna, e pela mesma letra minúscula, na linha, não diferem entre si, Tukey $5 \%$; Minimilho $=$ todas as espigas produzidas foram colhidas como minimilho; minimilho + milho verde $\mathrm{e}$ minimilho + milho seco $=$ a primeira espiga foi colhida como minimilho e as demais como milho verde ou como milho maduro, respectivamente). 
al., 2011). Likewise, we calculated the additional revenue (revenue increase in relation to production systems that did not receive nitrogen). Additional profit was obtained based on additional cost and additional revenue. We also calculated profitability index, defined as the percentage value from additional revenue that is converted into additional profit. Green corn and dry corn prices were obtained from local market producers (Mossoró). Values adopted were $\mathrm{R} \$ 0.47$ and $\mathrm{R} \$ 0.32$ per kilo, respectively. In the case of baby corn we adopted the mean value paid to suppliers of supermarkets in Natal, Rio Grande do Norte state and Fortaleza, Ceará state, that is, R\$ $10.00 \mathrm{~kg}^{-1}$. The mean price adopted for ammonium sulfate was R\$ $0.90 \mathrm{~kg}^{-1}$, obtained from prices practiced in Mossoró. Nitrogen fertilizer application costs were estimated at $\mathrm{R} \$ 40.00 \mathrm{ha}^{-1}$ (equivalent to two daily allowances).

\section{RESULTS AND DISCUSSION}

With regard to the number and weight of baby corn ears, total and marketable husked, there were effects of nitrogen levels $(\mathrm{N})$, production systems $(\mathrm{S})$, and the $\mathrm{S} \times \mathrm{N}$ interaction. In those traits, harvesting all ears as baby corn provided higher yields than harvesting the first ear as baby corn and harvesting the other ears as green or mature ears (Table 1). This occurred because in plots where only baby corn ears were harvested, as the ears were harvested new inflorescences were being formed, giving rise to new baby corn ears. The $\mathrm{S} \times \mathrm{N}$ interaction for total number of ears and number of husked, marketable ears was due to the fact that nitrogen increased those numbers when all ears were harvested as baby corn; however, the influence of nitrogen was null in the baby corn + green corn treatment and in the baby corn + dry corn production system (Table 1).

For total number of green ears, there were effects for nitrogen levels $(\mathrm{N})$ production systems $(\mathrm{S})$ and for the nitrogen levels $\times$ production systems interaction $(\mathrm{N} \times \mathrm{S})$. For total green ear weight and number and weight of marketable, unhusked and husked green
Table 2. Green corn yield means in corn cultivar AG 1051 depending on production systems and the application of different nitrogen levels (médias do rendimento de milho verde da cultivar de milho AG 1051, em função de sistemas de produção e de doses de nitrogênio). Mossoró, UFERSA, 2009.

\begin{tabular}{|c|c|c|}
\hline \multirow{2}{*}{$\begin{array}{l}\text { Nitrogen levels } x \\
\mathrm{~kg} / \mathrm{ha}\end{array}$} & \multicolumn{2}{|c|}{ Production systems } \\
\hline & Green corn & Baby corn + green corn \\
\hline \multicolumn{3}{|c|}{ Total number of green ears (x 1000/ha) } \\
\hline 0 & $49.58 \mathrm{Aa}$ & $20.19 \mathrm{Bb}$ \\
\hline 80 & $48.52 \mathrm{Aa}$ & $39.19 \mathrm{Ab}$ \\
\hline 160 & $50.02 \mathrm{Aa}$ & $34.13 \mathrm{Ab}$ \\
\hline \multicolumn{3}{|l|}{$\begin{array}{l}\mathrm{CV}(\%)_{\text {plots }}=14.8 \\
\mathrm{CV}(\%)_{\text {subplots }}=14.4\end{array}$} \\
\hline \multicolumn{3}{|c|}{ Total green ear weight (t/ha) } \\
\hline 0 & $8.53 \mathrm{Ba}$ & $2.19 \mathrm{Bb}$ \\
\hline 80 & $13.60 \mathrm{Aa}$ & $7.40 \mathrm{Ab}$ \\
\hline 160 & $15.18 \mathrm{Aa}$ & $6.04 \mathrm{Ab}$ \\
\hline \multicolumn{3}{|l|}{$\begin{array}{l}\mathrm{CV}(\%)_{\text {plots }}=17.5 \\
\mathrm{CV}(\%)_{\text {subplots }}=17.8\end{array}$} \\
\hline & \multicolumn{2}{|c|}{ Number of marketable unhusked ears (x 1000/ha) } \\
\hline 0 & $25.83 \mathrm{Ba}$ & $9.62 \mathrm{Bb}$ \\
\hline 80 & $46.12 \mathrm{Aa}$ & $18.78 \mathrm{Ab}$ \\
\hline 160 & $49.04 \mathrm{Aa}$ & $15.55 \mathrm{Ab}$ \\
\hline $\begin{array}{l}\mathrm{CV}(\%)_{\text {plots }}=13.3 \\
\mathrm{CV}(\%)_{\text {subplots }}=18.6\end{array}$ & & \\
\hline
\end{tabular}

\begin{tabular}{lcc}
\hline & Weight of marketable unhusked ears (t/ha) \\
\hline 0 & $5.82 \mathrm{Ba}$ & $0.20 \mathrm{Bb}$ \\
80 & $13.50 \mathrm{Aa}$ & $4.65 \mathrm{Ab}$ \\
160 & $15.02 \mathrm{Aa}$ & $3.62 \mathrm{Ab}$ \\
\hline
\end{tabular}

$\mathrm{CV}(\%)_{\text {plots }}=21.1$

$\mathrm{CV}(\%)_{\text {subplots }}=24.3$

\begin{tabular}{lcc}
\hline & Number of marketable husked ears (x 1000/ha) \\
\hline 0 & $14.36 \mathrm{Ba}$ & $0.00 \mathrm{Bb}$ \\
80 & $38.81 \mathrm{Aa}$ & $4.46 \mathrm{Ab}$ \\
160 & $41.71 \mathrm{Aa}$ & $5.06 \mathrm{Ab}$ \\
\hline $\mathrm{CV}(\%)_{\text {plots }}=28.1$ & & \\
$\mathrm{CV}(\%)_{\text {subplots }}=25.2$ & & \\
\hline
\end{tabular}

\begin{tabular}{lcc}
\hline & Weight of marketable husked ears (t/ha) \\
\hline 0 & $2.43 \mathrm{Ba}$ & $0.00 \mathrm{Bb}$ \\
80 & $7.80 \mathrm{Aa}$ & $0.82 \mathrm{Ab}$ \\
160 & $8.97 \mathrm{Aa}$ & $0.86 \mathrm{Ab}$ \\
\hline
\end{tabular}

$\mathrm{CV}(\%)_{\text {plots }}=37.0$

$\mathrm{CV}(\%)_{\text {subplots }}=32.0$

In each trait, means followed by the same uppercase letter in the column, and by the same lowercase letter in the row do not differ from one another, Tukey $5 \%$; Baby corn $=$ all ears produced were harvested as baby corn; baby corn + green corn and baby corn + dry corn $=$ the first ear was harvested as baby corn and the others were harvested as green corn or mature corn, respectively (em cada característica, médias seguidas pela mesma letra maiúscula, na coluna, e pela mesma letra minúscula, na linha, não diferem entre si, Tukey 5\%; Minimilho $=$ todas as espigas produzidas foram colhidas como minimilho; minimilho + milho verde $\mathrm{e}$ minimilho + milho $\operatorname{seco}=$ a primeira espiga foi colhida como minimilho e as demais como milho verde ou como milho maduro, respectivamente). 
Table 3. Dry corn yield and yield component means in corn cultivar AG 1051 depending on production systems and the application of different nitrogen levels (médias do rendimento de milho seco e seus componentes da cultivar de milho AG 1051, em função de sistemas de produção e de doses de nitrogênio, com respectivas equações de regressão). Mossoró, UFERSA, 2009.

\begin{tabular}{lcc}
\hline \multirow{2}{*}{ Nitrogen levels x kg/ha } & \multicolumn{2}{c}{ Production systems } \\
\cline { 2 - 3 } & Dry corn & Baby corn + dry corn \\
\hline 0 & $35.35 \mathrm{a}$ & $5.42 \mathrm{~b}$ \\
80 & $48.56 \mathrm{a}$ & $24.19 \mathrm{~b}$ \\
160 & $47.74 \mathrm{a}$ & $26.92 \mathrm{~b}$ \\
\hline $\mathrm{CV}(\%)_{\text {plots }}=14.9$ & & \\
$\mathrm{CV}(\%)_{\text {subplots }}=15.5$ & & $208 \mathrm{~b}$ \\
\hline & \multicolumn{2}{c}{ Number of kernels $/ \mathbf{e a r}$} \\
\hline 0 & $324 \mathrm{a}$ & $276 \mathrm{~b}$ \\
80 & $431 \mathrm{a}$ & $298 \mathrm{~b}$ \\
\hline 60 & $470 \mathrm{a}$ & \\
$\mathrm{CV}(\%)_{\text {plots }}=26.9$ & & \\
\hline
\end{tabular}

\begin{tabular}{llc}
\hline & \multicolumn{2}{c}{ 100-kernel weight (g) } \\
\hline 0 & $27.0 \mathrm{a}$ & $30.5 \mathrm{a}$ \\
80 & $35.0 \mathrm{a}$ & $32.4 \mathrm{a}$ \\
160 & $36.0 \mathrm{a}$ & $32.5 \mathrm{a}$ \\
\hline $\mathrm{CV}(\%)_{\text {plots }}=8.2$ & & \\
$\mathrm{CV}(\%)_{\text {subplots }}=18.4$ & & \\
\hline
\end{tabular}

\begin{tabular}{lll}
\hline & \multicolumn{2}{c}{ Grain yield (t/ha) } \\
\hline 0 & $2.89 \mathrm{a}$ & $0.32 \mathrm{~b}$ \\
80 & $7.32 \mathrm{a}$ & $2.16 \mathrm{~b}$ \\
160 & $8.24 \mathrm{a}$ & $2.62 \mathrm{~b}$ \\
\hline $\mathrm{CV}(\%)_{\text {plots }}=19.4$ & & \\
$\mathrm{CV}(\%)_{\text {subplots }}=20.2$ & & \\
\hline
\end{tabular}

In each trait, means followed by the same uppercase letter in the column, and by the same lowercase letter in the row do not differ from one another, Tukey $5 \%$; Baby corn $=$ all ears produced were harvested as baby corn; baby corn + green corn and baby corn + dry corn $=$ the first ear was harvested as baby corn and the others were harvested as green corn or mature corn, respectively (em cada característica, médias seguidas pela mesma letra maiúscula, na coluna, e pela mesma letra minúscula, na linha, não diferem entre si, Tukey 5\%; Minimilho $=$ todas as espigas produzidas foram colhidas como minimilho; minimilho + milho verde $\mathrm{e}$ minimilho + milho seco $=$ a primeira espiga foi colhida como minimilho e as demais como milho verde ou como milho maduro, respectivamente).

ears there were effects only for $\mathrm{N}$ and S. For all traits employed to evaluate green ear yield, green corn harvesting provided higher yields than baby corn + green corn harvesting (Table 2). Nitrogen did not influence the total number of green ears when all ears were harvested as green corn, but increased that trait in the baby corn + green corn treatment, resulting in the $\mathrm{S} \times \mathrm{N}$ interaction. Nitrogen increased similarly
$\mathrm{N} x \mathrm{~S}$ interaction effect on grain yield and its components (Table 3). Number of ears ha ${ }^{-1}$, number of kernels ear ${ }^{-1}$ and grain yield were higher when all ears were harvested as dry corn than in the baby corn + dry corn treatment, but there were no differences between systems for 100-kernel weight (Table 3).

For green corn (Table 2) and dry corn (Table 3), the number of ears formed when the first ear was harvested as baby corn was smaller than the number of ears produced when all ears were harvested as green or dry ears, respectively. Such reduction indicates that some plants did not produce subapical ears when the apical ear was harvested as baby corn. In addition, mature ears showed a smaller number of kernels per ear in the baby corn + dry corn production system (Table 3 ). A similar fact must have occurred with green ears, since there was a reduction in the number and weight (Table 2) of marketable husked green ears. These observations are in agreement with observations made by other authors (Silva et al., 2006). These facts may have resulted from pollination problems.

Corn is protandric, namely, the male inflorescence emerges before the emergence of the female inflorescence. When the second inflorescence was formed after removal of the apical ear, there may not have been pollen grain available to form new ears or fully-set ears. Pollination deficiencies may have occurred because of the dynamics of pollen release in corn. This dynamics tends to follow the Gauss curve, i.e., the amount of released pollen increases with time and then tends to decrease after reaching maximum values (Lizaso et al., 2003). Thus, the late-formed female inflorescences may have had smaller chances of being pollinated due to a reduced availability of pollen grain. In this sense, are beneficial breeding programs that reduce the interval between male and female flowerings. It is also possible that the weather conditions prevailing during the flowering period, particularly relative humidity and temperature, would have aggravated the reduction in pollination. Hot and dry environments reduce the viability of pollen grains (Purseglove, 
Table 4. Economic result parameters and costs to produce baby corn, green corn, and dry corn using corn cultivar AG 1051 depending on different production systems and nitrogen levels, in Brazilian Reais (R\$) [(custos e medidas de resultado econômico para produzir minimilho, milho verde e milho seco com a cultivar de milho AG 1051, em função de sistemas de produção e de doses de nitrogênio, em (Reais)]. Mossoró, UFERSA, 2009.

\begin{tabular}{|c|c|c|c|c|c|c|}
\hline \multirow[b]{2}{*}{$\begin{array}{l}\text { Production } \\
\text { systems }\end{array}$} & \multicolumn{2}{|c|}{ Costs } & \multicolumn{4}{|c|}{ Economic result parameters } \\
\hline & $\begin{array}{l}\text { Nitrogen } \\
\text { purchasing } \\
\text { (R\$/ha) }\end{array}$ & $\begin{array}{l}\text { Nitrogen } \\
\text { application } \\
\text { (R\$/ha) }\end{array}$ & $\begin{array}{c}\text { Total } \\
\text { revenue } \\
(\mathrm{R} \$ / \mathbf{h a})\end{array}$ & $\begin{array}{l}\text { Total additional } \\
\text { revenue } \\
\text { (R\$/ha) }\end{array}$ & $\begin{array}{c}\text { Additional } \\
\text { profit } \\
\text { (R\$/ha) }\end{array}$ & $\begin{array}{c}\text { Profitability } \\
\text { index } \\
(\%)\end{array}$ \\
\hline \multicolumn{7}{|c|}{$0 \mathrm{~kg} / \mathrm{ha}$ nitrogen } \\
\hline Baby corn (BC) & & & $33,630.00$ & 0 & 0 & 0 \\
\hline Green corn (GC) & & & $6,314.42$ & 0 & 0 & 0 \\
\hline Dry corn (DC) & 0 & 0 & 926.08 & 0 & 0 & 0 \\
\hline $\mathrm{BC}+\mathrm{GC}$ & & & $23,556.90$ & 0 & 0 & 0 \\
\hline $\mathrm{BC}+\mathrm{DC}$ & & & $20,643.04$ & 0 & 0 & 0 \\
\hline \multicolumn{7}{|c|}{$80 \mathrm{~kg} / \mathrm{ha}$ nitrogen } \\
\hline $\mathrm{BC}$ & & & $73,230.00$ & $39,600.00$ & $39,488.00$ & 53.9 \\
\hline $\mathrm{GC}$ & & & $10,064.00$ & $3,749.58$ & $3,637.58$ & 36.1 \\
\hline $\mathrm{DC}$ & 72.00 & 40.00 & $2,343.68$ & $1,417.60$ & $1,305.60$ & 55.7 \\
\hline $\mathrm{BC}+\mathrm{GC}$ & & & $45,442.30$ & $21,885.40$ & $21,773.40$ & 47.9 \\
\hline $\mathrm{BC}+\mathrm{DC}$ & & & $39,262.16$ & $18,619.12$ & $18,507.12$ & 47.1 \\
\hline \multicolumn{7}{|c|}{$160 \mathrm{~kg} / \mathrm{ha}$ nitrogen } \\
\hline $\mathrm{BC}$ & & & $103,790.00$ & $70,160.00$ & $69,976.00$ & 67.4 \\
\hline GC & & & $11,234.68$ & $4,920.26$ & $4,736.26$ & 42.2 \\
\hline $\mathrm{DC}$ & 144.00 & 40.00 & $2,636.16$ & $1,710.08$ & $1,526.08$ & 57.9 \\
\hline $\mathrm{BC}+\mathrm{GC}$ & & & $50,761.82$ & $27,204.92$ & $27,020.92$ & 53.2 \\
\hline $\mathrm{BC}+\mathrm{DC}$ & & & $40,109.36$ & $19,466.32$ & $19,282.32$ & 48.1 \\
\hline
\end{tabular}

Baby corn $=$ all ears produced were harvested as baby corn; baby corn + green corn and baby corn + dry corn $=$ the first ear was harvested as baby corn and the others were harvested as green corn or mature corn, respectively (minimilho = todas as espigas produzidas foram colhidas como minimilho; minimilho + milho verde e minimilho + milho seco = a primeira espiga foi colhida como minimilho e as demais como milho verde ou como milho maduro, respectivamente).

1972). In addition, late-fertilized ovules frequently abort, thus reducing the formation of grain (Cárcova et al., 2000; Anderson et al., 2004). Temperature $\left(31.4\right.$ to $33.7^{\circ} \mathrm{C}$ ) and relative humidity (42.9 to $49.3 \%$ ) during the flowering period of the plants evaluated in the experiment on which this paper is based were relatively high and low, respectively. Late silk emergence and incomplete kernel set after subapical ears are pollinated may indicate the occurrence of (Cárcova et al., 2000): a dominance mechanism exercised by the apical ear (Pinthus \& Belcher, 1994); competition for assimilates between apical and subapical ears (Tollenaar et al., 1992); or the simultaneous occurrence of both processes (Bangerth, 1989).

Nitrogen application provided increases in 12 of the 14 traits evaluated in this study (Tables 1, 2, and 3). The benefits from nitrogen fertilization would result from the effect of nitrogen on several processes in corn. Reductions in nitrogen availability cause reductions in the rate at which leaves appear, leaf area (Cathcart \& Swanton, 2004), and the longevity and photosynthetic activity of those leaves (Subedi \& Ma, 2005). In addition, the lack of nitrogen delays female flowering (Cathcart \& Swanton, 2004), the architecture and morphology of the root system (Duriex et al., 1994), and biomass partition dynamics (Evans et al. 2003) in corn. The $\mathrm{N}$ sources for developing kernels in corn consist of $\mathrm{N}$ absorbed from the soil and $\mathrm{N}$ remobilized from vegetative tissues (Gallais et al., 2007).

The coefficient of experimental variation values $(\mathrm{CV})$ were relatively high for total weight and weight of husked baby corn ears (Table 1) and for number and weight of marketable husked green corn ears (Table 2). The high values obtained were probably due to the low general means for those traits, not to low experimental precision. The low means occurred in traits where the lack of nitrogen application resulted in low or null yields. As an example, the highest $\mathrm{CV}$ values occurred for marketable husked green ear weight (Table 2). In that trait, yield values were null in $20 \%$ of the 54 plots (data not shown).

The values for total revenue and total additional revenue, as well as for additional profit, in descending order, were obtained with the production of baby corn $(\mathrm{BC})$, baby corn + green corn $(\mathrm{BC}+\mathrm{GC})$, baby corn + dry corn $(\mathrm{BC}+\mathrm{DC})$, green corn $(\mathrm{GC})$, and dry corn (DC), in all nitrogen 
levels (Table 4). The values for those measurements increased as nitrogen dose increased (Table 4). However, the production system that showed the highest profitability index was dependent upon nitrogen rate (Table 4). With the application of $80 \mathrm{~kg} \mathrm{~N} \mathrm{ha}^{-1}$, the highest profitability index was obtained from dry corn sales. However, with the application of the highest nitrogen rate, the highest profitability index was obtained from baby corn sales. It should be emphasized that the corn exploitation for babycorn production allows the early harvest in relation to harvest of green corn and dry corn. Moreover, babycorn production would result in larger quantities of fodder, resulting in additional profit to the grower.

Importantly, the data presented in this study were related to only one environment and using only one cultivar. Furthermore, the economic analysis was performed for the conditions of the municipality where the experiment was conducted and considering prices of December 2009. The average prices of three products evaluated vary throughout the year and this should also be taken into consideration.

It can be concluded, considering the conditions used in this work, that harvesting all ears as baby corn (BC) provided higher yields than harvesting the first ear as baby corn and harvesting the other ears as green or mature ears. For all traits employed to evaluate green corn yield (GC), harvesting green corn provided higher yields than harvesting baby corn + green corn $(\mathrm{BC}+\mathrm{GC})$. Harvesting baby corn + dry corn (BC + DC) provided lower grain yield values than harvesting all ears as dry corn (DC). The application of nitrogen provided increases in all traits evaluated, except for number of kernels ear ${ }^{-1}$, 100-kernel weight. However, response to nitrogen $(\mathrm{N})$ was higher or did not occur in some production systems (S), which motivated the occurrence of the $\mathrm{N} \times \mathrm{S}$ interaction. The revenue (total and additional total) and additional profit values, in descending order, were obtained with the production of $\mathrm{BC}, \mathrm{BC}+\mathrm{GC}, \mathrm{BC}+\mathrm{DC}, \mathrm{GC}$, and $\mathrm{DC}$, for all nitrogen levels. The values for those measurements increased as nitrogen dose increased. With the application of $80 \mathrm{~kg} \mathrm{~N} \mathrm{ha}^{-1}$, the highest profitability index was obtained from DC sales. However, with the application of the highest nitrogen rate, the highest profitability index was obtained from BC sales.

\section{ACKNOWLEDGEMENTS}

The first author thanks the Brazilian National Research Council (CNPq) for the productivity fellowship.

\section{REFERENCES}

AMARAL FILHO JPR; FORNASIERI FILHO D; FARINELLI R; BARBOSA JC Espaçamento, densidade populacional e adubação nitrogenada na cultura do milho. 2005. Revista Brasileira de Ciência do Solo 29: 467-473

ANDERSON SR; LAUER MJ; SCHOPER JB; SHIBLES RM. 2004. Pollination timing effects on kernel set and silk receptivity in four maize hybrids. Crop Science 44: 464-473.

BANGERTH F. 1989. Dominance among fruits/ sinks and the search for a correlative signal. Physiologia Plantarum 76: 608-614.

BLUMENTHAL JM; LYON DJ; STROUP WW. 2003. Optimal plant population and nitrogen fertility for dryland corn in Western Nebraska. Agronomy Journal 95: 878-883.

CANCELLIER LL; AFFÉRRI FS; CARVALHO EV; DOTTO MA; LEÃO FF. 2011. Eficiência no uso de nitrogênio e correlação fenotípica em populações tropicais de milho no Tocantins. Ciência Agronômica 42: 139-148.

CÁRCOVA J; URIBELARREA M; BORRÁS L; OTEGUI ME; WESTGATE ME. 2000. Synchronous pollination within and between ears improves kernel set in maize. Crop Science, 40: 1056-1061.

CARMO FILHO F; OLIVEIRA OF. 1989. Mossoró: um municipio do semi-árido nordestino. Mossoró: Fundação Guimarães Duque/ESAM. 62p. (Coleção Mossoroense. Série B. n.672).

CARVALHO GS; PINHO RGV; RODRIGUES VN. 2003. Produção de minimilho em diferentes ambientes de cultivo. Revista Ceres 288: 155-169.

CATHCART RJ; SWANTON CJ. 2004. Nitrogen and green foxtail (Setaria viridis) competition effects on corn growth and development. Weed Science 52: 1039-1049.

DURIEUX RP; KAMPHRATH EJ; JACKSON WA; MOLL RH. 1994. Root distribution of corn: the effect of N fertilization. Agronomy Journal 86: 958-962.

EMBRAPA. Centro Nacional de Pesquisa do Solo. 2006. Sistema brasileiro de classificação de solos. 2. ed. Brasília: EMBRAPA-SPI. 412p.

EVANS SP; KNEZEVIC SZ; LINDQUIST JL; SHAPIRO CA. 2003. Influence of nitrogen and duration of weed interference on corn growth and development. Weed Science 51: 546-556.

FAO. 1988. Soil map of the world, revised legend. Rome: UNESCO. 119p.

GALLAIS A; COQUE M; GOUIS JL; PRIOUL JL; HIREL B; QUILLÉRÉ I. 2007. Estimating the proportion of nitrogen remobilization and of postsilking nitrogen uptake allocated to maize kernels by nitrogen-15 labeling. Crop Science 47: 685-693.

HALLAUER AR. 1974. Heritability of prolificacy in maize. Journal of Heredity 65: 163-168, 1974.

KAMARA AY; MENKIR A; AJALA SO; KUREH I. 2005. Performance of diverse maize genotypes under nitrogen deficiency in the Northern Guinea Savanna of Nigeria. Experimental Agriculture 41: 199-212.

KÖPPEN W. 1948. Climatologia; con un estudio de los climas de la tierra. México : Fondo de Cultura Economica, $478 \mathrm{p}$.

LIMA RN; LIMA PO; CÂNDIDO MJD; PONTES FST; MOREIRA RHR; AQUINO RMS. 2011. Avaliação econômica de dietas líquidas à base de soro de queijo in natura para bezerros. Revista Brasileira de Saúde e Produção Animal 12: 14-21.

LIZASO JI; WESTGATE ME; BATCHELOR WD; FONSECAA. 2003. Predicting potential kernel set in maize from simple flowering characteristics. Crop Science 43: 892-903.

MOTTO M; MOLL RH. 1983. Prolificacy in maize: a review. Maydica 28: 53-76.

PINTHUS MJ; BELCHER AR. 1994. Maize top most axillary shoot interference with lower ear development in vitro. Crop Science 34: 458-461.

PURSEGLOVE JW. 1972. Tropical crops. I. Monocotyledons. New York, John Wiley. $334 \mathrm{p}$.

RIBEIRO JÚNIOR JI. 2001. Análises estatísticas no SAEG. Viçosa, Universidade Federal de Viçosa. 301p.

SILVA PSL. 2001. Desfolha e supressão da frutificação em milho. Revista Ceres 48: 55-70.

SILVA PSL; SILVA PIB; SOUSAAKF; GURGEL KM; PEREIRA FILHO IA. 2006. Green ear yield and grain yield of maize after harvest of the first ear as baby corn. Horticultura Brasileira 24: 151-155.

SILVA PSL; OLIVEIRA FHT; SILVA PIB. 2003. Efeitos da aplicação de doses de nitrogênio e densidades de plantio sobre os rendimentos de espigas verdes e de grãos de milho. Horticultura Brasileira 21: 454-457.

SUBEDI DK; MA BL. 2005. Nitrogen uptake and partitioning in stay-green and leafy maize hybrids. Crop Science 45: 740-747.

SVEČNJAK Z; VARGA B; BUTORAC J. 2006. Yield components of apical and subapical ear contributing to the grain yield responses of prolific maize at high and low plant populations. Journal of Agronomy and Crop Science 192: 37-42.

THAKUR DR; PRAKASH O; KHARWARA PC; BHALLA SK. 1998. Effect of nitrogen and plant spacing on yield, nitrogen uptake and economics in baby corn (Zea mays). Indian Journal of Agronomy 43: 668-671.

TOLLENAAR M; DWYER LM; STEWART DW. 1992. Ear and kernel formation in maize hybrids representing three decades of grain yield improvement in Ontario. Crop Science 32: 432-438.

VETSCH JA; RANDALL GW. 2004. Corn production as affected by nitrogen application timing and tillage. Agronomy Journal 96: 502-509.

WANG Z; STONE M; GRAY E. 2010. Effect of different schedules of baby corn (Zea mays L.) harvests on baby corn yield, grain yield, and economic return. Journal of the Kentucky Academy of Science 71: 59-66. 